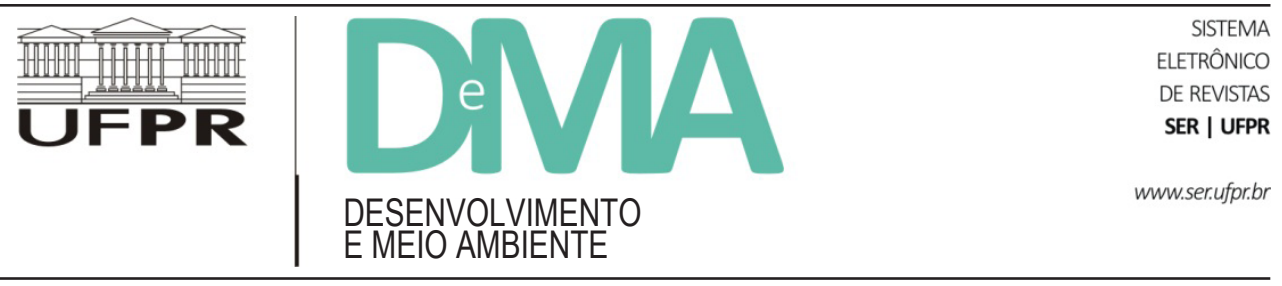

\title{
Buffers Against Inconvenient Knowledge: Brazilian Newspaper Representations of the Climate-Meat Link
}

\section{"Protegendo" o Brasil contra o "conhecimento inconveniente": a representação da conexão entre mudança climática e a carne bovina nos jornais brasileiros}

\author{
Myanna LAHSEN ${ }^{1,2 *}$ \\ ${ }^{1}$ Centro de Ciência do Sistema Terrestre, Instituto Nacional de Pesquisas Espaciais (INPE), São José dos Campos, SP, Brasil. \\ ${ }^{2}$ Environmental Policy Group, Wageningen University, The Netherlands. \\ *E-mail of contact: myannal@gmail.com
}

Article received in November 14, 2016, final version accepted in February 16, 2017.

ABSTRACT: Analyzing Brazilian newspapers' climate coverage leading up to 2010, this article shows that climate change was framed as an energy problem although energy is a small part of the country's emissions compared to emissions from land use change and agriculture. Linked to well over half of national emissions, meat production is the single largest cause of national emissions. Yet discussions of meat as a problem in the context of climate change were marginal, at best. During the years $2007-2008$, only $0.14 \%$ of climate change-mentioning articles $-0.01 \%$ of the total word count of climate change-mentioning articles - were dedicated to meat as a problem in the context of climate change. Counting also passages in articles not dedicated to the topic, the word count only rose to $0.13 \%$ of the total word flow of the articles. To the extent that the topic of meat as a problem appeared, it was underdeveloped and approached in ways that reduced attention, concern, and agency on the part of Brazilians to steer the country towards a new, more sustainable development path. This paper presents these findings and offers a preliminary political economic explanation for its existence.

Keywords: media coverage; climate change; energy; meat; solutions.

RESUMO: Analisando a cobertura sobre o clima nos jornais brasileiros nos anos 2002 até 2010, este artigo mostra que a mudança climática foi enquadrada como um problema de energia, apesar de ela ser uma pequena parte das emissões do país em comparação com as emissões de mudança no uso da terra e da agricultura. Enquanto a produção de carne é a maior causa das emissões nacionais, discussões sobre a carne como um problema no contexto das alterações climáticas foram marginais, na melhor das hipóteses. Na medida em que apareceu, $o$ tema da carne era subdesenvolvido e abordado de tal forma que reduziu a atenção, a preocupação e o poder dos brasileiros para guiar o país para um novo caminho de desenvolvimento nacional mais sustentável. $\mathrm{O}$ artigo apresenta esses resultados e oferece uma explicação econômica e política preliminar.

Palavras-chave: cobertura midiática; mudança climática; energia; carne; soluções. 


\section{Introduction}

Energy production generates more greenhouse gases globally than livestock raised for food, but extensive cattle grazing and intensive feedlots cause deforestation and are major drivers of regional and global change (McAlpine et al., 2009). Estimates of greenhouse gas emissions from livestock globally vary greatly depending on methodology, ranging from approximately one fifth of global emissions to $51 \%$ or more (Goodland, 2013). Compared to energy, reducing beef consumption is increasingly recognized as an especially quick and efficient means of achieving over one fourth of the needed greenhouse gas reductions by 2050 while also promoting healthier diets (de Boer et al., 2016), reducing the risk of long-term food insecurity (Foley et al., 2011), cancer (Popkin, 2009) and antibiotics resistance, among a longer list of threats (Kanaly et al., 2009; Pachauri et al., 2014). In all world regions, the average person consumes more protein than the daily requirement (Ranganathan et al., 2016). For these reasons, more efficient and space-wise intensified meat production is an insufficiently systemic solution. Because beef is an extremely inefficient source of protein (see Figure 1), multiple planets would be necessary to feed the world's growing population the same amount of red meat consumed by the average American or Brazilian (Ranganathan et al., 2016).

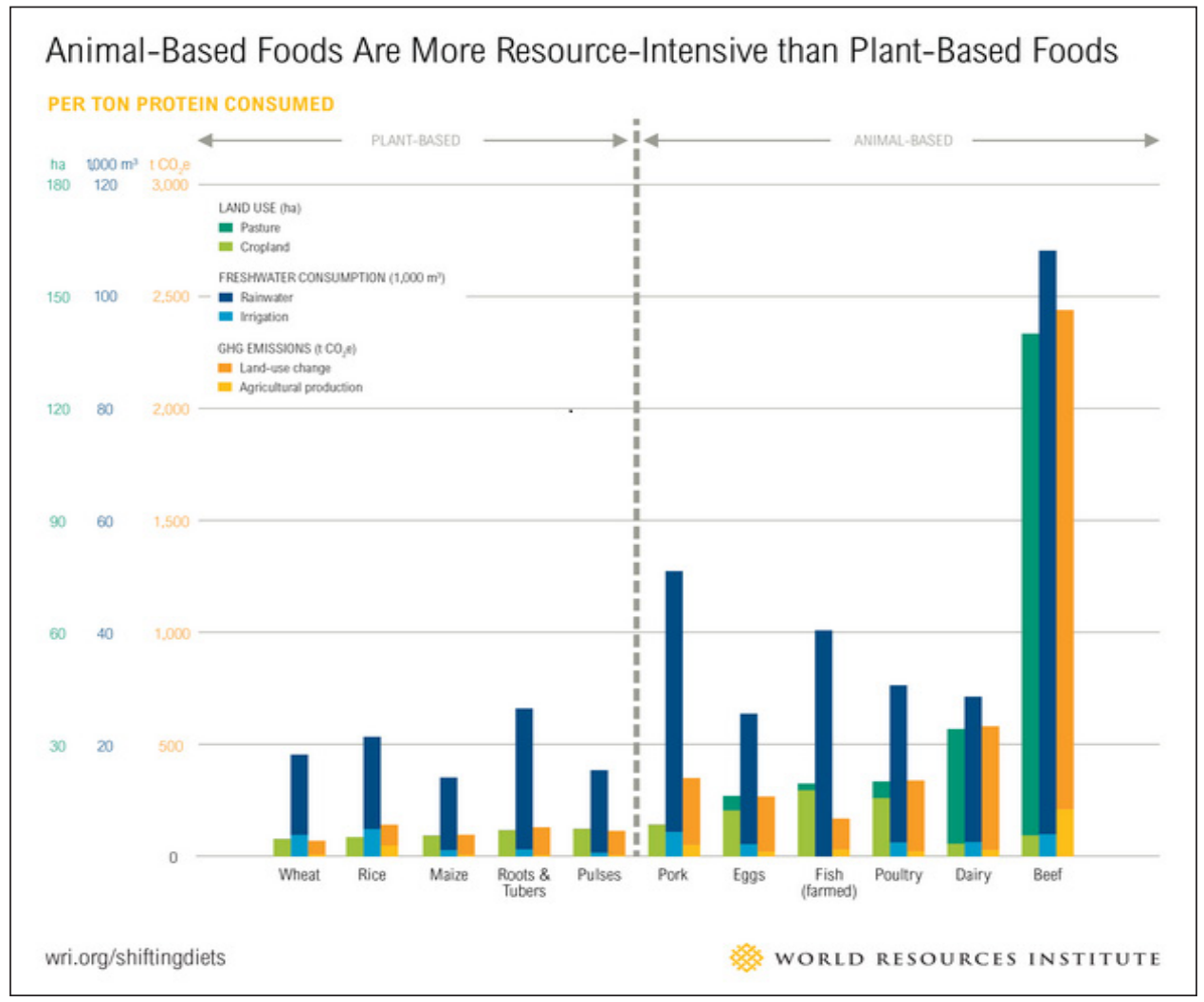

FIGURE 1 - Resource intensity of beef compared to other sources of protein, including rice and beans (pulses). SOURCE: Ranganathan et al. (2016 p. 4). 
Given its many negative impacts on environment, health and natural resource conservation, international authorities judge meat production in whichever form an ill-advised, high risk investment choice for financial speculators as well as middleand lower-income countries seeking to realize their development aspirations (Kanaly et al., 2009; TRUCOST, 2015). Reducing meat consumption is an especially potent way of reducing emissions because, as a whole, individuals can relatively easily reduce their meat consumption by opting for nutritionally adequate and - also generally cheaper - existent plant-based alternatives. By contrast, low-emitting alternative energy sources tend to be less accessible economically and involve higher dependence on mediating macro-level policy, which often is influenced by high-polluting (fossil fuel) interests and path dependence (Urry, 2004; de Boer et al., 2016).

In Brazil, meat production, including soy for animal feed, is the biggest single source of its national emissions because it also is a key driver of land use (McAlpine et al., 2009). Leading Brazilian scientists have estimated that at least half of national emissions resulted from meat production, excluding consideration of emissions from transportation (Bustamante et al., 2012). More recent estimates tie 62\% (Barreto, 2015) and 69\% (Agência do Brasil, 2016) of national emissions to livestock. According to Brazil's 2010 National Inventory submitted to the United Nations Framework Convention on Climate Change (UNFCCC), eighty percent of national greenhouse gases were emitted by the closely linked categories of land use change and agriculture, while energy production released approximately fifteen percent of national emissions (MCT, 2010). Emissions from energy have risen in recent years but the combined emissions from the (overlapping) categories of land use and agriculture and livestock continue to contribute the majority (see Figure 2). The relatively low energy emissions reflect Brazil's high deforestation rates and its energy independence policies to produce most electricity from hydroelec-

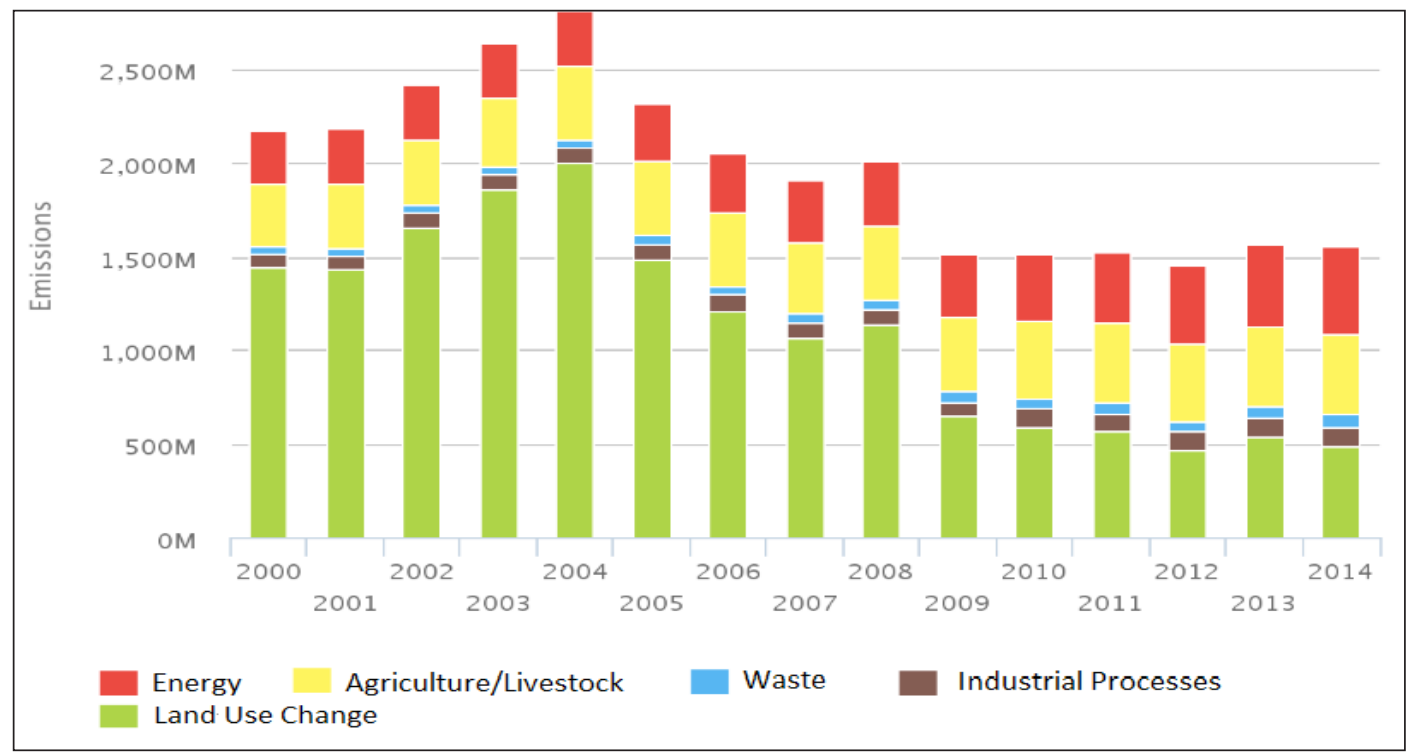

FIGURE 2 - Brazil's Emissions Profile: Contributions of Brazil's economic sectors. SOURCE: Translated from SEEG (2015). 
tric dams and transportation fuel from sugar cane. Despite important reported reductions in deforestation rates since a peak in 2004 the rates remain high at approximately 5000 square kilometers per year in the Amazon and 7000 square kilometers in the Savanna region, according to government figures. Driven centrally by meat and soy production, the frontier expansion is rapidly advancing into - and thus destroying - pristine ecosystems essential to the country's food, water and energy security (Lahsen et al., 2016).

Most (70-80\%) of Brazil's meat is consumed domestically (ABIEC, 2015), and the average Brazilian in São Paulo eats more meat than the average American. $81 \%$ of men and $58 \%$ of women consume more meat than the maximum of 700 grams per week recommended by Brazil's Healthy Eating Index Revised (already higher than the upper limit of 500 grams a week specified as healthy in the United States), exceeding by 1.9 (men) and 1.1 times (women) the maximum intake limit recommended by the World Cancer Research Fund (Carvalho et al., 2013).

It is in the overall public interest that the country's national mass media spread awareness that meat is a problematic development choice and an exceptionally inefficient and carbon-intensive source of protein, and that they nurture debate about desirable alternatives. In stark contrast, as will be shown here, Brazilian newspapers' climate coverage includes exceptionally little coverage of - and correspondingly a virtual absence of national debates about - consumption-related changes needed to address climate change beyond the energy sector. This analysis focuses centrally on the period from the early 2000s to 2010, with central attention to the years 2007-2008, the two years following the release of the high profile report by the United Nations Food and Agriculture Organization (FAO),
Livestock's Long Shadow, which called attention to the deleterious environmental consequences of meat, and the then surprising definition of livestock as contributing $18 \%$ of global emissions, more than the transportation sector (Steinfeld et al., 2006).

\section{Inclinations and limitations in media coverage of the Climate-Meat link}

Often complex and deeply-embedded in socio-cultural norms, framing is a means by which social actors - frequently strategically, but not always even consciously - "construct" reality by characterizing it (Snow \& Benford, 1992). When frames are hegemonic, they are absorbed into cultural understanding of the world and largely taken for granted (Rosas-Moreno 2010). Which framings prevail in any given discussion or society is important because they are a means of "mind management" affecting societal attitudes and responses (Dijk, 1993, p. 257).

Discourses perpetuate social power by naturalizing privileged access to socially valued resources, including status, wealth and the environment (Freudenburg, 2005), and privileged access to discourse and communication channels is a key factor in ensuring power and dominance to some over others. Research informed by agenda-setting theory has established that an issue's frequent appearance and prominence in news reporting increases public perceptions of it as important (McCombs \& Shaw, 1972).

Drawing on a vast body of literature similarly attentive to how discourses shape subjectivities, Carvalho (2010) draws attention to media discourses' role in shaping citizens' perceptions of their own agency, cultivating dispositions to action or inaction. Despite discourses to the contrary, climate 
change politics tend to reinforce status quo (Park et al., 2008; Swyngedouw 2010) and "exclusionary constructions" (Carvalho, 2010, p. 175) that deny citizens' meaningful engagement with the issue.

The media play a vital role in stimulating public concern on the basis of factual knowledge, yet studies in a variety of national contexts show that mainstream news media tend to be averse to tackling the issue to an extent concomitant with its importance. Despite a net increase, Neff et al. (2009) study of sixteen of the top twenty most read US newspapers showed scant coverage of food systems' contributions to climate change during the period from September 2005-January 2008. Only $0.5 \%$ of climate change mentioning articles during that period mentioned food animal contributions. Kiesel's (2010) study of media coverage of the FAO's 2006 report (Steinfeld et al. 2006) in British and American newspapers from the report's launch in November 2006 and two years forward found that only six articles in The Guardian and The Observer and three in The New York Times discussed the climate-livestock or the climate-meat consumption link. Despite generally acknowledging the link, they approached the topic with caution and avoided moralizing food choices.

Friedlander et al.,'s (2014) study of climate focused articles in leading Australian newspapers from 2008-2013 similarly found that slightly less than one percent $(0.956 \%)$ also mentioned meat-related terms. Almiron \& Zoppeddu's (2015) study of Spanish and Italian newspapers between November 2006 and September 2013 found a higher numbers of articles about the link but similarly highlighted a media "blind spot" with regards to the topic. Of the articles clearly addressing the topic of climate change in a central manner, $11 \%$ included mention of meat and/or livestock in the full text in both countries. In this body of centrally climate focused articles, 102 articles $(1.5 \%)$ in the Spanish newspapers and 36 articles $(3.6 \%)$ in the Italian newspapers clearly addressed the impact of meat eating/production on climate change/global warming.

The higher percentages in the more recent studies of Australia, Spain and Italy likely reflect the gradual increase in attention to the climate-meat link also evident in Neff et al.'s (2009) results.

\section{Methodology}

Part of an international, intercomparative research project probing tendencies in media coverage, policy debates, and policy actor networks across the world (for more on the project, see www. compon.org and Broadbent, 2016), our research integrated COMPON's standardized methodology, the first level of which analyzes climate coverage in three major national print newspapers. COMPON teams chose to focus centrally on climate change coverage during the years 2007-2008 in three major daily print newspapers in each nation studied, ideally choosing newspapers of varied political orientations.

Three leading newspapers with national circulation were chosen: Folha de São Paulo (300,000 printed copies per day and estimated readership of nearly 1.5 million), Estado de São Paulo (henceforth Estado SP, approximately 228 print copies per day and a readership of 1.14 million), and Valor Econômico (more specialized and business-oriented, printed approximately 64.000 copies per day), all estimates for the year 2010. Politically, Brazil's daily newspapers are broadly similar, lacking in political diversity. Folha $S P$ is slightly less to the right, or centrist, but this does not translate into perceptible differential climate coverage (Painter \& Ashe, 2012). 
The articles were retrieved from the online $\mathrm{Fac}$ tiva data searching for any one of three common terms for climate change in Portuguese: climate change, climate changes, and global warming (mudança climática, mudanças climáticas, aquecimento global). Articles that did not mention climate in their title or initial 1-2 paragraphs were retained, except if the references were not meaningfully about climate change. Factiva offers full access from 2002 to 2016 to only two Brazilian newspapers: Folha SP and $O$ Globo. Access to Valor Econômico and Estado SP begins in 2002 but ends in mid-2009 and mid-2011, respectively. Figure 3 presents these variations and a post-2009 drop in coverage in line with international trends (Broadbent, 2016).

Informed by Critical Discourse Analysis that power and dominance is exercised through "subtle, routine, everyday forms of text and talk that appear natural and quite 'acceptable'" (Dijk, 1993, p. 254) while silencing certain types of knowledge and perspectives, the content analysis attended to how the newspapers framed the link between climate and meat, thus guiding perceptions and behavior. The content analysis had multiple components. The climate-mentioning articles were searched for references to meat, cattle and cow as well as

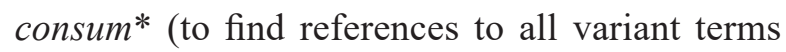
for consumption, consume, etc. and analyze the objects in focus). To avoid redundancy and due to space limitations, the content analysis centered on Estado SP and the years 2007-2008. Since the FAO report was released in November 2006, references to the FAO in the 2006 Estado SP articles were also analyzed to see how that landmark report was covered. A delimited but revealing analysis of Folha SP's treatment of meat in 2007 was also performed to illustrate similarity across these two newspapers.

In the study of Estado SP, consumption references in 20 percent of all the climate-mentioning articles from 2007 and 2008 were analyzed, on the standard methodological premise (Broadbent et al., 2016) that 20 percent of a large sample of newspaper articles is representative of the whole. This served as a snap shot of general tendencies. To be sure not to have missed anything important, all references to meat, cattle and cow in the remaining 80 percent were subsequently analyzed, limiting our attention to those that were meaningfully related to the topic of climate change or the environment more broadly. This included meat references in articles that mentioned but were not centrally focused on climate.

In the keyword analysis, all references to meat, cattle and cow were counted. The content analysis excluded the following: articles (1) that had nothing to do with neither livestock nor climate or (2) that only mentioned the impact of climate on agribusiness, including livestock and grain production, not the inverse; (3) in which the meat/cattle/cow references were not linked to climate or the link was overly implicit or indirect and/or (4) the link was insufficiently developed to carry significant meaning related to meat and climate change. A total of eight articles were discarded due to (3) and (4). ${ }^{1}$

\footnotetext{
${ }^{1}$ These were: In 2007: “Clima - uma nova oportunidade?” 20 August; “Alteração do clima já é grave. Etanol é nova ameaça ao cerrado," 1 August; "BIOCOMBUSTÍVEL. Para ambientalista, desflorestamento no bioma já está mais acelerado do que na Amazônia,” 1 July; "Uma Cúpula Mundial do Clima," 4 March. In 2008: "Água virtual das commodities," 20 March; “'Sou um ecoansioso, quero tudo resolvido"”, 15 December; "Um pasto com lavoura e árvores" 27 August; “As licenças ambientais perderam a pressa," 6 August. One of them - "Clima - uma nova oportunidade?" 20 August 2007 - could perhaps have been included but it was disconsidered because its meat relevance is limited to this single sentence in the middle of the text: "Qual é o sentido de queimar 15 mil quilômetros quadrados de floresta amazônica por ano, para criar gado, o que lança na atmosfera mais gases que provocam o aquecimento global do que toda a Inglaterra?" (Title: "Climate - a New Opportunity." Text: "What is the point of burning 15,000 square kilometers of Amazon forest per year to raise cattle, which launches more global warming-causing gases into the atmosphere than England.")
} 


\section{Broad characteristics of Brazilian newspapers' climate coverage}

\subsection{A post 2009 drop in climate coverage}

Figure 3 shows the variation in media attention as reflected in the number of climate-change mentioning articles in the newspapers per year. It reveals broad similarity in the ebbs and flows of coverage across the newspapers, with a steep drop in coverage after 2009 that characterizes news coverage world wide (Broadbent, 2016).

\subsection{An overwhelming focus on energy issues,} unreflective of the national emissions profile

Searching the full set of climate-mentioning articles for references to consum* ("consumption" and variant terms such as "consume", "consuming," etc.) and examining the objects in focus, we discovered that consumption discussions overwhelmingly focused on energy issues, alternative fuels in general and biofuels in particular. Figures 4-6 show the total number and frequency of references to alternative energy, biofuels, alcohol and ethanol in Portuguese (energia renovável, energias renováveis, biocombusti ${ }^{*}$, alcóol, and etanol), all presented in shades of green and contrasted to the low number of references to meat, variously including and excluding related terms such as "cattle" and "cow(s)" shown in shades of red and brown. During the two year period 20072008, Estado SP had 12.5 times more references to the keywords for renewable fuels compared to meat/ cattle/cow (carne(s), gado, boi): 1577 versus 126 references. Our content analysis below reveals that many of the references to the latter in fact included exceedingly few discussions about animal protein production and consumption as a problem in the context of climate change. Yet, even casting the net widely in this manner, the references were orders of magnitude lower than references to alternative energy and variant terms, a mere subcategory of a much larger number of energy references not represented here.

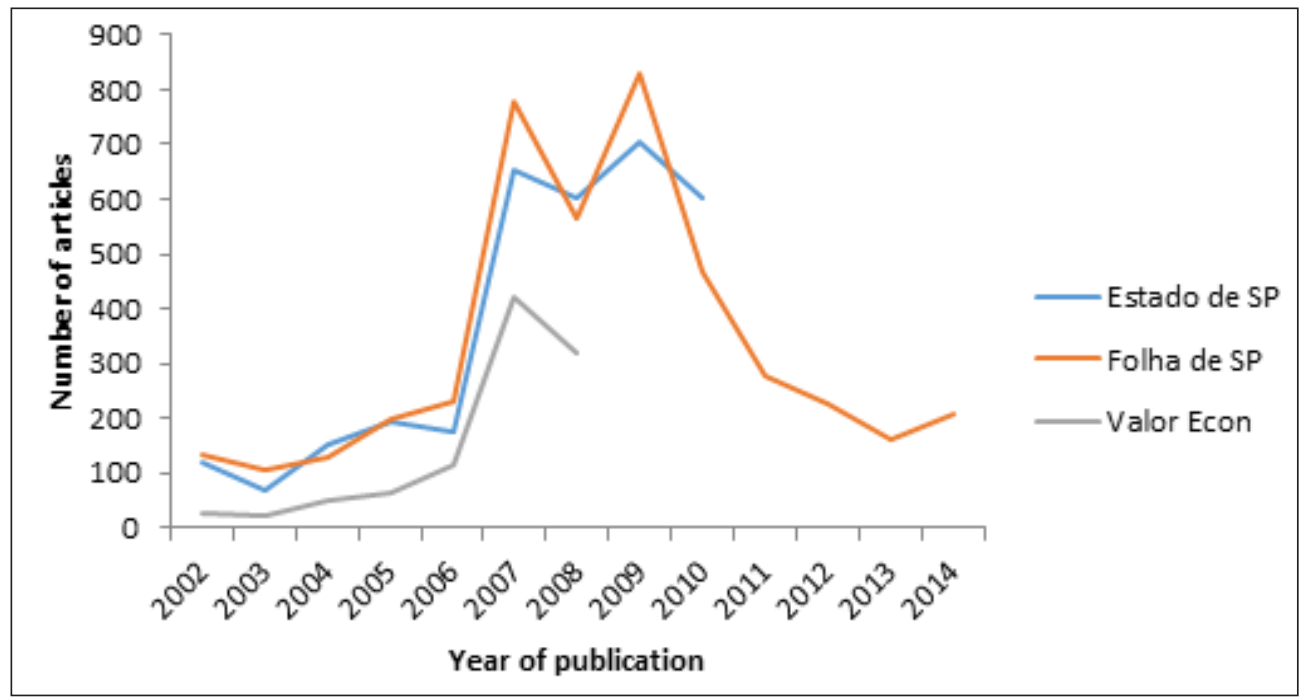

FIGURE 3 - Number of articles that mention climate change (three terms in Portuguese) in the three selected Brazilian newspapers per year. 


\section{Estado de São Paulo}

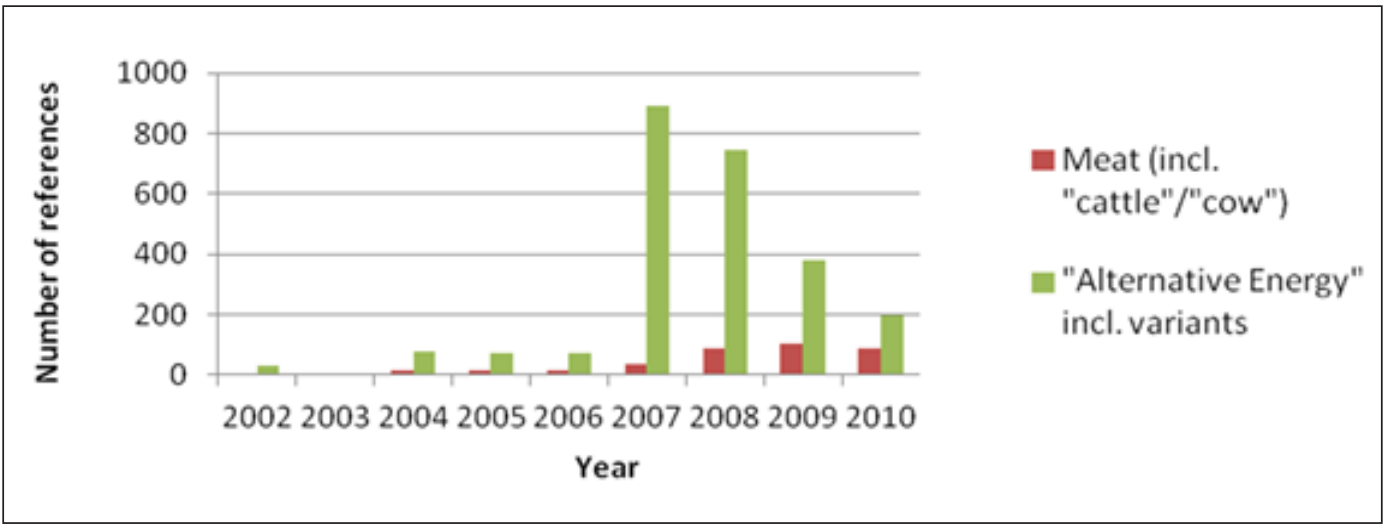

Estado de São Paulo
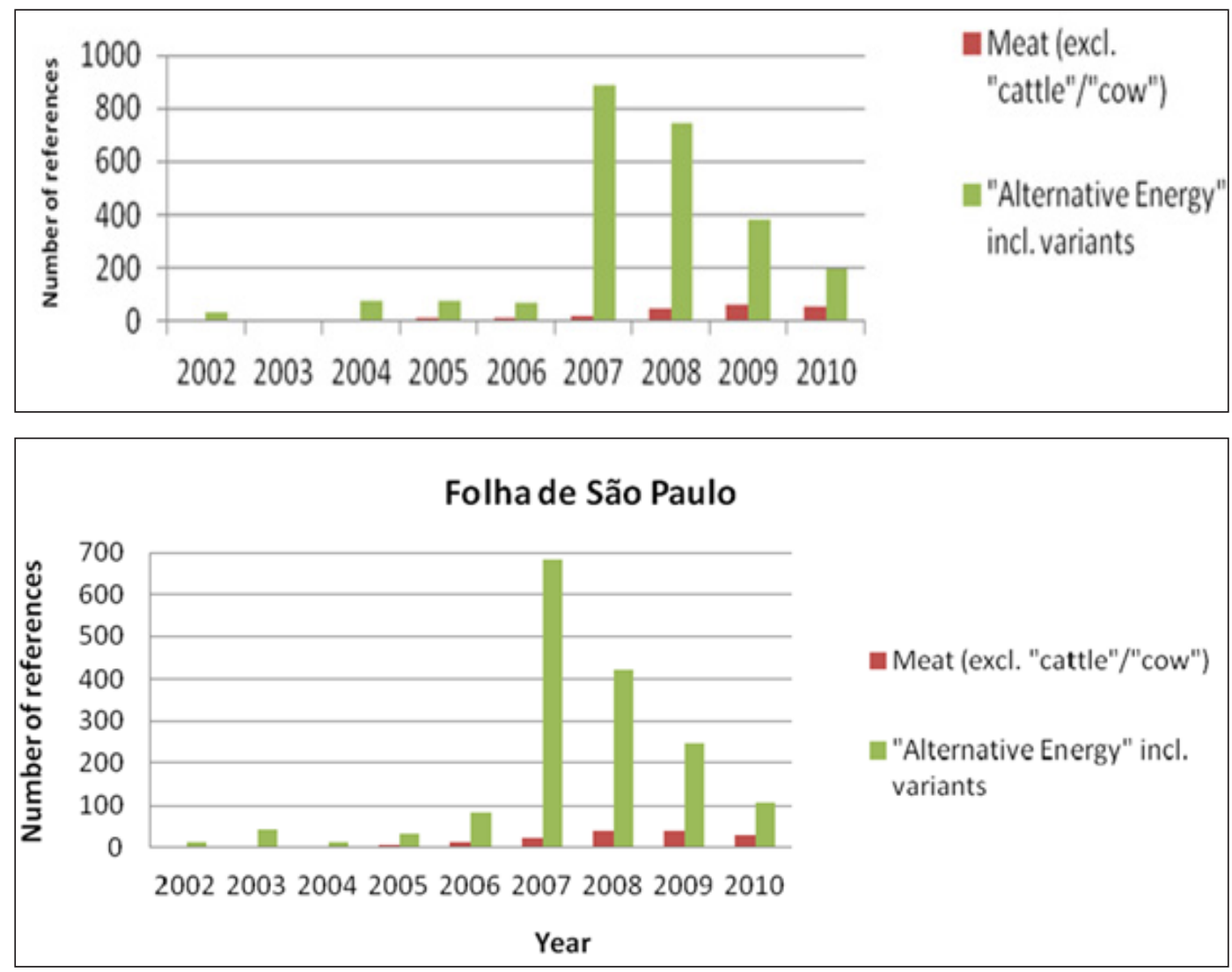

FIGURE 4 - Number of references to meat in Estado SP and Folha SP from 2002-2010. Including references to cattle and cow in addition to meat did little to reduce the strong contrast to the high number of references to renewable energy (especially ethanol). Observe that the results from the two newspapers are nearly identical. 


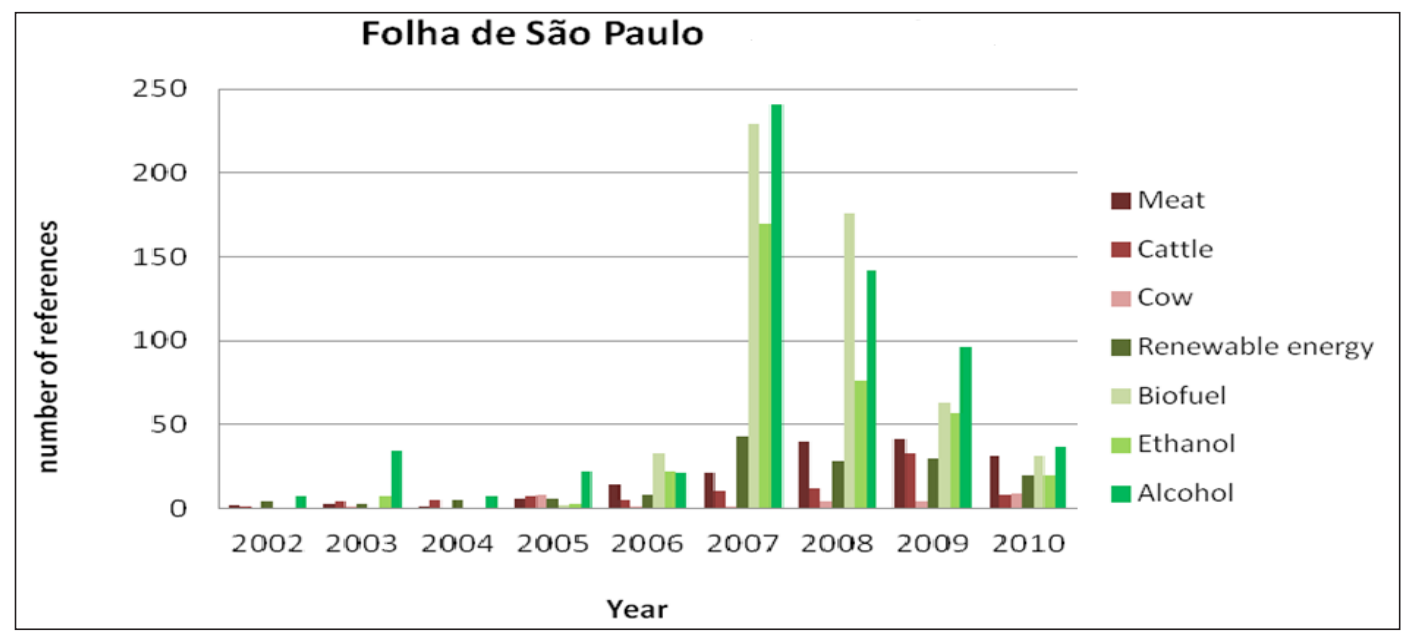

FIGURE 5 - Number of references to meat versus alternative energy per year in Folha SP 2002-2010, specifying the relative representativeness of the different terms.

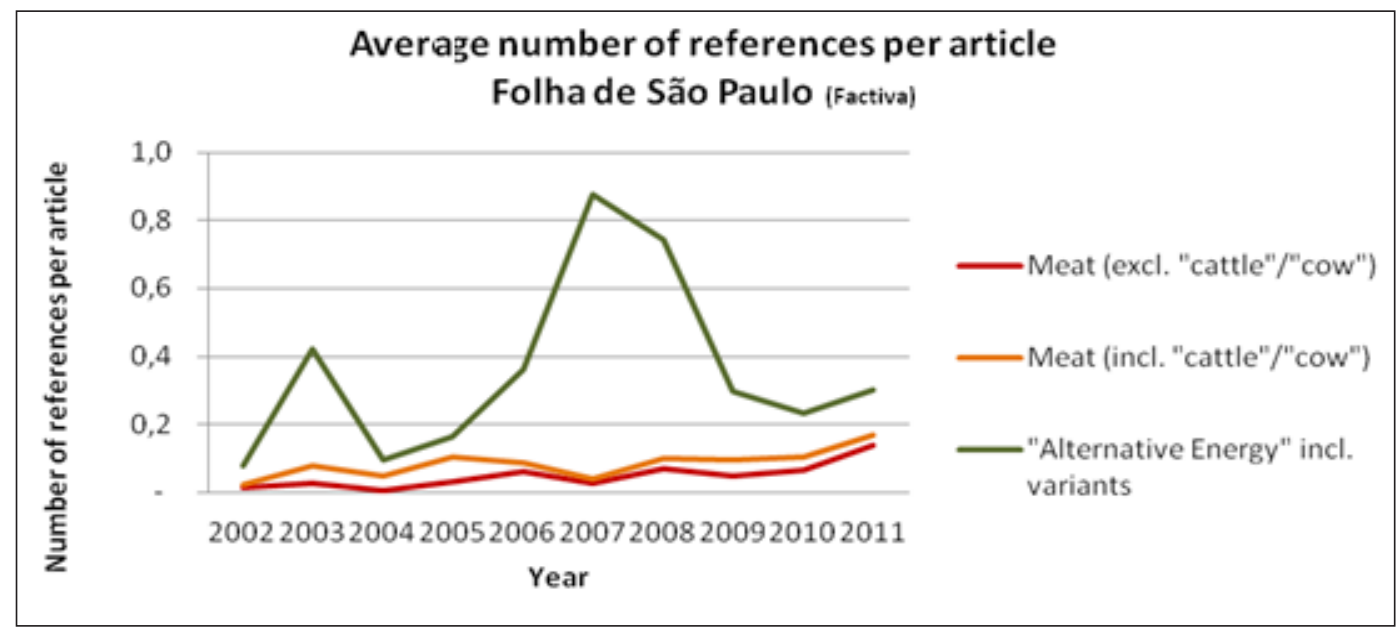

FIGURE 6 - This graph shows the same data (plus 2011) for Folha SP as in figure 5, but in terms of average number of references, thus compensating for periodic spikes and reductions in the volume of articles.

The surge in references to biofuels in 20072008 reflects the increasing attention to it as an economic opportunity for Brazil and other developing countries and a solution to the problem of climate change, a proposal advanced aggressively by then president "Lula" Inácio da Silva. Brazilian ethanol produced from sugar cane is an important dynamic sector of the country's economy and was the focus of large-scale foreign investments during that time but waned somewhat in importance after the industry encountered setbacks as well as mounting criticisms that the rapid expansion of sugarcane contributed to food price spikes, deforestation and other environmental and social ills. 


\section{Content analysis}

A content analysis of the full body of climate-mentioning articles in Estado SP in 2007 and 2008 that also mention the words meat, cattle and cow revealed that substantial meat discussions were exceedingly few, and that not a single article was singularly dedicated to such a discussion, much less to detailed exploration of the challenges of a meat transition for Brazil. When references were made to meat consumption as a problem, discussions were with few exceptions limited to a few sentences, buried in larger articles with other foci. Moreover, as we illustrate further below, Brazilian journalists tended to play down cause for concern and action, also by choosing not to further explore the topic and its particular relevance for Brazil.

We found little difference between the newspapers.

\subsection{Estado $S P$}

In 2007 and 2008, Estado SP published 783 and 622 articles, respectively, that mentioned one of the three terms for climate change in Portuguese, summing 1405 articles in total, or 765217 words. Of these only four $-0.28 \%$ of the articles, or $0.02 \%$ of their combined word count - were centrally dedicated to topics about the climate-meat link, including two articles which contested the underpinning science, as described below. Excluding the latter two, the numbers dwindled to two articles representing $0.14 \%$ of the total. The content of these articles will be analyzed in detail below.

\subsubsection{Illustrative analysis of a 20 percent sample}

\section{Brevity and foreign voices or sources}

In the randomly selected $20 \%$ subset of Estado SP articles from 2007 and 2008, eleven articles addressed consumption in some relatively significant way in the context of climate change, specifying thirteen objects. Seven of the eleven articles mentioned - and with one exception were mainly about - energy, mostly (six of the seven) emissions from transportation. Three discussed sustainable industrial production and recycling efforts, and another three focused on emissions from food, two of which approached the topic of meat. Whereas the seven articles with energy/transportation foci each averaged around 900 words (approximately 6300 words), these two articles together totaled a mere 151 words, five sentences, and they were the only articles that centrally and directly approached both climate change and meat consumption as a problem in that context. One was two sentences about a British study concluding that the country's population should reduce consumption of meat and dairy products to reduce greenhouse gas emissions. ${ }^{2}$ Firmly limited to the British population, there was no journalistic effort to expand and relate this finding to Brazilian consumption habits. The same applies to the second article, ${ }^{3}$ a three sentences long notice about Paul McCartney's defense of vegetarianism as a means of combatting climate change and protect the environment. Both its title ("..says ex-Beatle") and body text ("According to McCartney ... meat is among the main causes of

\footnotetext{
2 "Estudo inglês sugere limitar carne e leite," Estado SP, 1 Oct. 2008.

3 “Comer carne é ameaça ao clima, diz ex-Beatle,” Estado SP, 21 April 2008.
} 
climate change and environmental degradation" emphasis added) convey a distanced, unengaged stance with regards to his claim despite its backing in science. Both were foreign in origin and either foreign or generic/global in their focus, rather than the product of active Brazilian journalism.

\section{Energy-focused solutions}

One of the above articles about energy consumption illustrates the pervasive silence on the meat issue in articles not analyzed below because they do not contain the keywords meat/cattle/cow. Published in June 2008 - nearly two years after the FAO report - and titled "It's time for carbon emission reductions," it cited the United Nations and the need for behavior changes to reduce emissions. A Brazilian expert on climate science and politics, physicist Gylvan Meira Filho, was consulted and cited. He only mentioned energy choices, not dietary ones:

The basic recipe involves alternative energy sources - or at least greater efficiency in the use of traditional energy sources - and more conscious consumption, considering that about $85 \%$ of the energy consumed in the world is generated by the burning of oil, coal and natural gas. In addition, of course, to forest conservation.

\section{Lengthy contestations of science supporting} concern about meat

In the full set of climate change-mentioning articles from both years, only two other articles addressed the climate-meat link in a dedicated manner. They did so from angles of contestation, however, respectively framing the link as a non-problem and as a lesser problem than claimed internationally.
"Watery beef" is the title of a 900 word scathing dismissal of meat as an environmental problem by Xico Graziano, an agronomy-trained former Secretary of São Paulo's State Secretariat of the Environment and a regular columnist in the newspaper. Graziano berates a "dangerous mixture of ecological neurosis and cultural prejudice" which "criminalizes" cow burbs and meat consumption when, he claims, "beans, among other foods, cause similar problems for humans." In addition to being antagonistic, this framing hides the crucial difference that producing beans is much less resourceand greenhouse gas emitting compared to meat (see figure 1). Graziano calls technical calculations of methane emissions "deceiving" and ideological, and dismisses environmentalists and the FAO for fictitious, apocalyptic accusations against the livestock sector. Ignoring the issue of water pollution provoked by pesticides to produce pastures and soy for cattle, the loss of freshwater recycling that results from deforestation, and more generally the risks it poses to the country's food and energy security, Graziano argues that the livestock sector is in balance with nature and that since cows urinate out the liquids they ingest, the net water loss from meat production is zero.

Titled "Kyoto rules overestimate impacts of methane emissions," in Table 1) does not mention consumption but is focused on the methodology used under the Kyoto Protocol to calculate the global warming potential ("GWP" - CO2 equivalence) of methane, livestock's major direct contribution to climate change. Presenting technical arguments rather than virulent anti-environmental rhetoric (hence its lighter red

\footnotetext{
4 “A hora e a vez da redução das emissões de carbono," Estado SP, 5 June 2008.

5 "Bife aguado," Estado SP, 8 May 2007.

6 “Regras de Kyoto superestimam impacto das emissões de metano," Estado SP, 16 December 2007.
} 
colored background in the table), this exceptionally long article of 1749 words advances the Brazilian government's charge that the methodology overestimates methane's GWP by more than 400 percent, thus attributing "exaggerated guilt" to Brazil, in which methane is the source of $20 \%$ of the country's emissions, $70 \%$ of which is from livestock's enteric fermentation.

These two articles contesting facts central to the climate-meat link and associated concern total 2649 words, more than double the (1019) words of all the remaining articles/passages in the core-set and residual category discussed below; in total, the climate-meat/cattle link confirming text in this corpus add up to a mere 46 sentences.

Articles \#1 and \#2 present contestations of the science bearing on the climate-meat link. The stronger red indicates virulent contestation absent in the article shown with a lighter red background, which similarly takes issue with elements of the science underpinning concern about livestock, but on the basis of more measured, technical argument.
With content confirming the climate-meat link as a problem, articles \# 3 and \#4 are shown with a solid row of green.

\subsubsection{Residual articles not centrally focused on both climate and meat}

Beyond the articles in Table 1, discussions about meat occurred only in articles not centrally focused on the climate-meat link. None of these contested the science underpinning concerns about the climate-meat link or that it might be a problem. Eleven such articles approached the climate-meat link in a direct manner (as opposed to indirectly, e.g. the role of cattle in deforestation), however briefly. Of these, only one article ${ }^{7}-$ an interview with Intergovernmental Panel of Climate Change (IPCC) chairman Rajendra Pachauri - centrally focused on climate and featured text urging reduced meat consumption ( 1 sentence, 14 words, in a 100-word paragraph about the more general need to change lifestyles). Three other articles were also

TABLE 1 - The core set: Articles in Estado de São Paulo 2007-2008 that centrally and directly approach both climate change and its link to meat

\begin{tabular}{|c|c|c|c|c|c|c|}
\hline & Article title \& & Word & $\begin{array}{l}\text { Climate in title } \\
\text { or } 1^{\text {st }} \text { paragraph }\end{array}$ & $\begin{array}{l}\text { Dominant focus on } \\
\text { meat as problem; }\end{array}$ & $\begin{array}{l}\text { Mentions need } \\
\text { for reduced meat } \\
\text { consumption }\end{array}$ & $\begin{array}{c}\text { Contests climate- } \\
\text { meat link and/or } \\
\text { related science }\end{array}$ \\
\hline 1 & $\begin{array}{l}\text { Bife aguado } \\
8-5-2007\end{array}$ & 900 & yes & yes & no & yes \\
\hline 2 & $\begin{array}{l}\text { Regras de Kyoto superestimam } \\
\text { impacto das emissões de } \\
\text { metano } \\
16-12-2007\end{array}$ & 1,749 & yes & yes & no & yes \\
\hline 3 & $\begin{array}{l}\text { Comer carne é ameaça ao } \\
\text { clima, diz ex-Beatle } \\
21-4-08\end{array}$ & 81 & yes & yes & yes & no \\
\hline 4 & $\begin{array}{l}\text { Estudo inglês sugere limitar } \\
\text { carne e leite } \\
1-10-08\end{array}$ & 70 & yes & yes & yes & no \\
\hline
\end{tabular}

${ }^{7}$ Mundo deve ajudar a preservar Amazônia," Estado SP, 18 October 2007. 
centrally about climate and mentioned meat as a problem but without entering into the question of whether to reduce consumption. The discussions were buried in the text and clear but undeveloped and brief, summing 297 words. ${ }^{8}$ Additional articles approached the topics of climate and cattle or meat somewhere in the text but were not centrally about climate, totaling 557 words spread over 18 sentences in six articles. Of these, three approached meat as a problem due to their emissions and resource intensity; several were about water use rather than climate change. I will refer to this entire set of articles as the "residual group" of articles. Some of their noteworthy features and shared characteristics will be discussed below. With the 151 words from the two non-contesting core-set articles, all these discussions in the two years amounted to total of 1019 words, representing $0.13 \%$ of the words in the full set of climate mentioning articles those two years.

\section{Journalistic underexploration of the meat topic}

One article ${ }^{9}$ centrally focused on climate (and the Amazon) featuring an explicit plea for reduced meat consumption was an interview with IPCC chairman Rajendra Pachauri in which he - buried in the sixth paragraph - stressed that countries such as Brazil should want to seek alternative development paths to the unsuccessful, fateful one of developed countries, "including new dietary habits," he said, adding: "If I could give a recommendation, I would even ask for meat consumption to be reduced." The journalist did not follow up on the topic. Instead, he steered the interview towards the environmentally and economically more comfortable topic of ethanol, ending it with Pachauri's comment that Brazil's sugarcane-derived ethanol is "the good [kind]." Pachauri here adopted a more cautious discourse than he does in other contexts. The words "If I could..." and "even" could indicate awareness that the topic is especially sensitive given Brazil's less developed status (its people claim the right to adopt richer diets) and the importance of meat in Brazilian culture and economy. Pachauri makes lengthier and more forceful pronouncements in news outside of Brazil. In a clear, direct and thorough discussion in on article ${ }^{10}$ in The Guardian dedicated to the climate-meat link one month earlier, he was described as "blam[ing] meat eaters for visiting environmental mayhem on the world as the demand for beef drives deforestation, water scarcity, air pollution and climate change." The article also offered vivid information related to readers' daily choices: "changing eating habits to become a vegetarian does more to fight global warming than switching from a gas-guzzling SUV to a fuel-efficient hybrid car." No such discussion was found in any of the Brazilian articles

The lack of further exploration when references to the meat topic create openings for doing so is characteristic of the newspapers' coverage in

\footnotetext{
${ }^{8}$ All by the same columnist, Washington Novaes, these articles were: (1) “O Direito para um mundo novo," 9 Nov. 2007 - 4 short sentences ( 87 words) in the 9th paragraph cite the FAO's conclusion that livestock production needs to reduce its resource use and impacts by $50 \%$, asserting in consent that the sector - despite its irritation - needs to comply; (2) “O clima esquentou mesmo. E agora?," 23 Feb. 2007 - one sentence (50 words) citing the same FAO conclusion, but without further elaboration; (3) "Os riscos do clima para setor," 5 Sept. 2008 - 2 sentences (160 words) about environmentalists in Germany who, going against the agribusiness lobbies, sought to instigate discussion about the emissions from the sector and about taxes on products such as meat and cheese for that reason.

9 "Mundo deve ajudar a preservar Amazônia," Estado SP, 18 October 2007.

10 "UN says eat less meat to curb global warming," The Guardian, 7 Sept. 2008. Accessible at: < https://www.theguardian.com/environment/2008/ sep/07/food.foodanddrink $>$.
} 
general. For example, one of the other articles in the non-core set of articles relates climate change and the FAO's recommendation to reduce global beef consumption by at least fifty percent. Nevertheless, it proceeds to discuss only the need to reduce deforestation and invest in alternative energy such as solar and wind.

\section{Ghettoized in the environmental beat}

The residual set of articles are not centrally about both climate and meat or cattle but nevertheless contain subparts with meaningful references if not full-fledged critical discussion about meat. No less than eight of these eleven articles - nearly four fifths - are by the same columnist, the environmental journalist Washington Novaes. This suggests a "ghettoization" of the topic, as opposed to its absorption into the broader range of news coverage beyond the environmental beat. Novaes' articles offer the most critical, direct and extensive treatments of the topic in the newspaper. He was also the only one to bring up the FAO's report in the wake of its release in the climate-mentioning Estado SP articles from 2006. Even so, during the full two year period, Novaes did not write a single article dedicated to the climate-meat link and what to do to address it, not even when he covered the newly released FAO's report in 2006.

\section{Disempowered and disempowering language}

Despite his leading role in raising the topic of meat as a problem in the context of global environmental change, Washington Novaes transmits a pervasive sense of power- and hopelessness. This is already apparent in the titles of several of his first articles. His first article about the FAO report in 2006 was titled "The U.N. is screaming. Who will listen?"11 Another "Two decades of warnings. And so/now what?" After his description of Pachauri's urge that Brazil seek a low-meat and generally more sustainable development path, Novaes punctuates the paragraph with a curt, pessimistic comment: "Difficult" before turning to another topic. Interestingly, even Novaes rarely - in only two of his eight meat/cattle/cow-mentioning articles in 20072008 - brings critical discussion about meat in the context of climate change to explicit discussion of consumption. The implied solutions are rarely taken to that level, and not once did he specifically discuss Brazilian habits. Most often, the meat-related discussions were brief, buried in the middle and towards the end, and he kept the discussion at the level of generality (the need to change global trends), or focused on rich countries' greater responsibility to change their habits (e.g., in the article titled "No Centro, a água, a terra, o sol," 20 March 2008).

\subsection{Similar characteristics in Folha SP}

Brazilian journalists play down the message

Folha SP also had scant discussions of meat. A search for "consum*" in Folha SP's 712 climate-mentioning articles in 2007 revealed only two articles with discussions related to meat, only one of which approached the need to reduce its consumption. ${ }^{12}$ Written by an environmentally committed journalist, the article is uncharacteristic due to its length and also its prominent message that meat consumption is a problem. It cited Pachauri's urge for humanity to "change its lifestyle and its

\footnotetext{
11 “A ONU está gritando. Quem vai ouvir?,” Estado SP, 8 Dec. 2006.

${ }^{12}$ The article without the specified message is "O frango, a gravata e a sustentabilidade," Folha de São Paulo, 28 June 2007. The second, the one featuring Pachauri, is "Crise do clima precede guinada cultural," Folha de São Paulo, 6 May 2007.
} 
consumption patterns" and an African scientist saying that the change in habit "does not require much sacrifice." Similarly to the pattern in Estado $S P$, the discussion left off here, however, without further details and exploration of the associated opportunities and challenges for Brazil. And rather than inspiring action and agency, the latter article's ending softens conclusions by noting that driving a car fifty kilometers per day for a year emits as much as the production of 800 kilos of meat and - with the same vital omissions as in Graziano's reference to beans in Estado SP - that "vegetarians won't become the champions of climate overnight" because rice also emits methane. The message transmitted is disempowering, inducing a sense that there are no real alternatives, if humans are to eat.

In Folha SP, articles found through our search for the keywords meat, cattle and cow (and subsequently verified for their climate relevance) made up $0.38 \%$ of all climate-mentioning articles in 2007 and $0.52 \%$ in 2008 . This places Brazil as the country with similarly low but comparatively lowest coverage of the topic compared to the other national studies reviewed above, where meat was the focus or mentioned in $0.5 \%$ (USA), $0.956 \%$ (Australia), and in $11 \%$ or $1.5 \%$ (Spain) and $3.6 \%$ (Italy). Yet in Brazil, contrary to these other countries, meat contributes the larger part of its emissions.

\section{Accounting for the identified tendencies}

Energy is an appropriate framing at the global level and in many foreign countries, but it misrepresents Brazil's greenhouse gas emissions profile. Played out in newspapers, the distortion leaves the public un(der)informed about the extent to which meat contributes to climate change and needs to be reduced to addressed it, thereby also suppressing diverse, democratic and substantive discussion about Brazil's challenges and opportunities associated with the demeatification of diets that science and international institutions increasingly advocate as necessary for long-term food security and mitigation of climate change. Lack of information and journalistic capacity could result in frame importation from abroad. However, the consistent downplaying of the issue - also among informed journalists, as documented above - suggests the role of other factors. Novaes" "Difficult" comment reflects his awareness of the formidable challenge of challenging the country's economic emphasis on livestock and the associated unsustainable extractivist economic model, not least because the agro-cattle industry is the biggest lobby and extremely powerful in Brazil.

Meat eating is a strong part of Brazilian social life and culinary tradition, and journalists may shun it to avoid being perceived as a "drag" ("chato"), as a prominent Brazilian environmental reporter explained in an interview with me. His explanation echoes discoveries in the US, Sweden and Canada of non-governmental environmental organizations' reluctance to take on the cause of reducing meat consumption because they perceive it as an issue with limited social and political appeal and are hesitant to tell people what to do (Laestadius et al., 2014). Adding to the difficulty in Brazil, meat eating is associated with status and social mobility, and Brazilians are led to believe that the agribusiness sector and exports are an inalterable pillar in the country's gross national product, inducing a feeling of post-ecological powerlessness (Blühdorn, 2007) in the face of information about the agribusiness sector's unsustainability, to the extent that they are helped to be aware of it in the first place. 


\section{Conclusion}

Examining Brazilian newspapers' coverage of the role of meat as a driver of climate change, we have identified and discussed a series of interlinked tendencies towards silence, avoidance and minimization of the problem. In line with this, studies reviewed above have found the climate-meat link to be underrepresented in a number of other countries' media. In his study of newspaper coverage in the United States during the same period as examined here, Neff et al. (2009) found that only $0.5 \%$ of climate change-mentioning articles during that period mention the link. Subsuming also more recent years, studies of newspaper coverage in Spain and Italy found that a whopping eleven percent of climate-focused articles mention meat and/or livestock and that of the centrally climate-focused articles, $1.5 \%$ in Spanish newspapers and 3.6\% in Italian newspapers clearly address the impact of meat eating/production on climate change/global warming.

This study shows that the numbers are significantly lower in Brazil by comparison, even though beef is the single largest source of national emissions in Brazil, a reality not shared with the other countries. Excluding science-contesting articles, only $0.14 \%$ of Estado SP's climate-mentioning articles were dedicated to the climate-meat link, $0.01 \%$ of the total word count, and the sum of the meat-related passages in the residual category (few of them centrally about climate, none of them centrally about meat as a problem in the context of climate change) amount to only $0.13 \%$ of the words in the 2007-2008 climate-mentioning articles. Studying the same time period, Kiesel (2010) found few articles on the climate-meat link in U.K. and U.S. newspapers, but just the single, above-mentioned The Guardian article ("UN says eat less meat to curb global warming," 7 September
2008) contains 747 words and is content-wise of much higher quality - more extensive, thorough and informative - than the 1019 words spread out over thirteen articles bearing on the climate-meat link in Estado SP in 2007 and 2008. Unlike any of the Estado SP text, it tells people that they should have a meat-free day a week, if they wish to be part of the solutions to climate change, and explains why cutting down on meat is an effective and especially quick way to reduce emissions.

This author is aware of no other countries in which the newspaper bias is so strong as to amount to a misdiagnosis of the major national source of greenhouse gas emissions. These findings beg analysis of Brazilian media coverage in more recent years and further empirical exploration of the factors that suppress rigorous journalism better capable of informing and stimulating broad-based, vigorous, forward-looking and democratic debate about the challenges and opportunities that a transition to less meat presents for Brazil.

Given these formidable forces in favor of a continued emphasis on meat production despite its disastrous consequences, the media are especially needed as a force to make interventions in dominant norms and ways of thinking. Numerous recent reports (ADC, 2008; Reporters Without Borders, 2013) identify strong mechanism of control operating through Latin American media and which serves elite and business interests. These mechanisms include repressive elements of the dictatorship periods that have variously remained in place or mutated into more subtle means of censorship and control (ibid.). Governments in the region also abuse their financial and regulatory powers over the media, for example by using advertising funds and licensing processes on which the media are dependent for their survival, to variously reward or punish them (ibid.). In Brazil, the distinction between the country's formidable agricul- 
tural lobby and its government is blurred (Machado, 2013), and a sizeable part of the country's elected politicians - many of them part of the agribusiness lobby - are also media owners, despite constitutional prohibitions against it (Estado SP, 2015).

\section{Acknowledgements}

Sincere thanks to Gabriela Couto, Luciana Ferreira, Carla Moura, Janaina Michelini, Isabel Gnaccarini and Maria Alice da Paula who all assisted with various parts of the article collection and data processing. Special thanks to Gabriela Couto for assistance with the graphs. The research benefited from support from the US National Science Foundation (grant no. 1544589) and from the Brazilian Counsel of Technological and Scientific Development $(\mathrm{CNPq})$ for the project "Science, Technology and Policy Studies" (CNPq 483099/2009-0) under the Brazilian National Institute for Science and Technology - Climate Change (INCT-MC).

Broadbent, J. et al. Conflicting climate change frames in a global field of media discourse. Socius: Sociological Research for a Dynamic World, 2, 1-17, 2016.

Bustamante, M. M.; Nobre, C. A.; Smeraldi, R.; Aguiar, A. P.; Barioni, L. G.; Ferreira, L. G.; Longo, K.; May, P.; Pinto, A. S.; Ometto, J. P. Estimating greenhouse gas emissions from cattle raising in Brazil. Climatic Change, 115, 559-577, 2012.

Carvalho, A. Media(ted) discourses and climate change: A focus on political subjectivity and (dis)engagement. WIRES Climate Change, 1(2), 172-179, 2010.

Carvalho, A. M. de; Selem, S. S. de C.; Miranda, A. M.; Marchioni, D. M. Excessive red and processed meat intake: relations with health and environment in Brazil. British Journal of Nutrition, 115(11), 2011-2016, 2013.

De Boer, J.; de Witt, A.; Aiking, H. Help the climate, change your diet: A cross-sectional study on how to involve consumers in a transition to a low-carbon society. Appetite, 98, 19-27, 2016.

Dijk, T. A. v. Principles of critical discourse analysis. Discourse \& Society, 4(2), 249-283, 1993.

Estado de São Paulo. Coronelismo Radiofônico. 30 November, 3, 2013. 
Foley, J. A.; Ramankutty, N.; Brauman, K. A.; Cassidy, E. S.; Gerber, J. S.; Johnston, M.; Mueller, N.D.; O'Connell, C.; Ray, D. K.; West, P. C. Solutions for a cultivated planet. Nature, 478, 337-342, 2011.

Freudenburg, W. R. Privileged access, privileged accounts: toward a socially structured theory of resources and discourses. Social Forces, 84(1), 89-114, 2005.

Goodland, R. Lifting livestock's long shadow. Nature Climate Change, 3, 2, 2013.

Kanaly, R. A.; Manzanero, L. I. O.; Macer, D.; Panneerselvam, S. Energy Flow, Environment and Ethical Implications for Meat Production. Ethics and Climate Change in Asia and the Pacific (ECCAP) Project. RUSHSAP, UNESCO, Bangkok, 2009.

Kiesel, L. A comparative rhetorical analysis of US and UK newspaper coverage of the correlation between livestock production and climate change. In: Seitz, E.; Wagner, T.; Lindenfeld, L. (Eds.). Proceedings of the 10th Biennial Conference on Communication and the Environment. Portland, OR. Retrieved from https://theieca. org/contents-2009-conference-communication-and-environment-proceedings, 2010.

Lahsen, M.; Bustamante, M. M.; Dalla-Nora, E. Undervaluing and Overexploiting the Brazilian Cerrado at Our Peril. Environment: Science and Policy for Sustainable Development, 58, 4-15, 2016.

Laestadius, L. I., Neff, R. A.; Barry, C. L.; Frattaroli, S. "We don't tell people what to do:" An examination of the factors influencing NGO decisions to campaign for reduced meat consumption in light of climate change. Global Environmental Change, 29, 32-40, 2014.

Machado, M. Doação ou investimento? A atuação legislativa dos parlamentares da bancada ruralista e a questão do financiamento de campanhas. Thesis (Bachelor) - Universidade de Brasília, 2013.

McAlpine, C. A.; Etter, A.; Fearnside, P. M.; Seabrook, L.; Laurance, W. F. Increasing world consumption of beef as a driver of regional and global change: A call for policy action based on evidence from Queensland (Australia), Colombia and Brazil. Global Environmental Change, 19, 21-33, 2009.

MCT - Ministério de Ciência e Tecnologia. Segunda Comunicação Nacional do Brasil à Convenção-Quadro das
Nações Unidas sobre Mudança do Clima. Brasília, Brasil, 2010 .

Neff, R. A.; Chan, I. L.; Smith, K. C. Yesterday's dinner, tomorrow's weather, today's news? US newspaper coverage of food system contributions to climate change. Public Health Nutrition, 12, 1006-1014, 2009.

Pachauri, R. K.; Allen, M.; Barros, V.; Broome, J.; Cramer, W.; Christ, R.; Church, J.; Clarke, L.; Dahe, Q.; Dasgupta, P. Climate Change 2014: Synthesis Report. Contribution of Working Groups I, II and III to the Fifth Assessment Report of the Intergovernmental Panel on Climate Change, 2014.

Painter, J.; Ashe, T. Cross-national comparison of the presence of climate scepticism in the print media in six countries, 2007-10. Environmental Research Letters, 7, 044005, 2012. doi: 10.1088/1748-9326/7/4/044005

Park, J.; Conca, K.; Finger, M. The crisis of global environmental governance: towards a new political economy of sustainability. New York, Routledge, 2008.

Popkin, B. M. Reducing meat consumption has multiple benefits for the world's health. Archives of Internal Medicine, 169, 543-545, 2009.

Ranganathan, J. et al. Shifting diets for a sustainable food future. Working paper, installment 11 of creating a sustainable food future, World Resources Institute, Washington, DC, 2016.

Reporters Without Borders. Brazil, the country of 30 Berlusconis, 2013. Available at: <http://en.rsf.org/IMG/pdf/ brazil_report.pdf $>$.

Rosas-Moreno, T. C. Media representations of race cue the state of media opening in Brazil. International Journal of Communication, 261, 261-282, 2010.

SEEG - Sistema de Estimativa de Emissões de Gases de Efeito Estufa. Available at: $<$ http://seeg.eco.br/tabela-geral-de-emissoes/>, 2015.

Snow, D. A.; Benford, R. D. Master frames and cycles of protest. In: Morris, A. D.; Mueller, C. M. Frontiers in Social Movement Theory. London, New Haven, Conn: Yale Univeristy Press, 1992. p. 133-155.

Steinfeld, H.; Gerber, P.; Wassenaar, T. D.; Castel, V.; de Haan, C. Livestock's long shadow: environmental issues and options. United Nations Food and Agriculture Organization, 2006. 
Swyngedouw, E. Apocalypse forever? Post-political populism and the spectre of climate change. Theory, Culture \& Society, 27(2-3), 213-232, 2010.

TRUCOST. 2015. Natural Capital Risk Exposure of the Financial Sector in Brazil [Online]. Report by Brazilian Council of Businesses for Sustainable Development
(CEBDS) and the German Council for International Collaboration (GIZ). Available at: <http://cebds.org/wp-content/ uploads/2015/07/GIZ-Natural-Capital-Risk-Exposure.pdf.>

Urry, J. The 'system'of automobility. Theory, Culture \& Society, 21(4-5), 25-39, 2004. 
